\title{
Effects of Different Inducer on the Accumulation of Essential Oil from Endophytic Fungi of Cinnamomum longepaniculatum
}

\author{
Kuan Yan ${ }^{1,2}$, Ping Yuan ${ }^{*}$, Qin Wei ${ }^{2}$ \\ ${ }^{1}$ College of Sichuan Tea, Yibin University, Yibin, China \\ ${ }^{2}$ College of Life Science and Food Engineering, Yibin University, Yibin, China \\ Email: 7761052886@qq.com
}

How to cite this paper: Yan, K., Yuan, P. and Wei, Q. (2019) Effects of Different Inducer on the Accumulation of Essential Oil from Endophytic Fungi of Cinnamomum longepaniculatum. Open Access Library Journal, 6: e5337.

https://doi.org/10.4236/oalib.1105337

Received: March 14, 2019

Accepted: April 8, 2019

Published: April 11, 2019

Copyright $\odot 2019$ by author(s) and Open Access Library Inc.

This work is licensed under the Creative Commons Attribution International License (CC BY 4.0).

http://creativecommons.org/licenses/by/4.0/

\section{(c) (i) Open Access}

\begin{abstract}
The aim of this study was to investigate the effect of different inducer on the accumulation of essential oil in $C$. longepaniculatum endophytic fungus. The effect of the essential oil accumulation in the $C$. longepaniculatum fungus was studied by adding different inducer with an $C$. longepaniculatum endophytic fungus (serial number 2J1) with the ability of producing essential oil. The results show that the accumulation of essential oil can be greatly promoted by adding $\mathrm{CaSO}_{4} 1.5 \mathrm{mg} / \mathrm{L}, \mathrm{H}_{2} \mathrm{O}_{2} 9 \mathrm{mmol} / \mathrm{L}$, SA $15 \mathrm{mg} / \mathrm{L}$ and $\mathrm{MnSO}_{4} 3 \mathrm{mmol} / \mathrm{L}$ in the PDB medium; compared with $\mathrm{CK}$ in the same condition increased $75.56 \%, 47.18 \%, 38.35 \%, 53.95 \%$ respectively; reached $0.0934 \mathrm{mg} / \mathrm{L}, 0.0783$ $\mathrm{mmol} / \mathrm{L}, 0.0736 \mathrm{mmol} / \mathrm{L}, 0.0819 \mathrm{mg} / \mathrm{L}$; through the orthogonal experiment, the combinations $2.0 \mathrm{mg} / \mathrm{L} \mathrm{CaSO}_{4}, 12 \mathrm{mmol} / \mathrm{L} \mathrm{H}_{2} \mathrm{O}_{2}, 5 \mathrm{mg} / \mathrm{L} \mathrm{SA}$ and 7 $\mathrm{mmol} / \mathrm{L} \mathrm{MnSO}_{4}$ were significantly different from other combinations; the yield reached $0.1847 \mathrm{mg} / \mathrm{L}$ and increased by $247.18 \%$, indicating that adding inducer was an effective way to promote the accumulation of essential oil of endophytic fungi. This provides a reference for the artificial regulation of the secondary metabolites of $C$. longepaniculatum and the enhancement of subsequent microorganisms.
\end{abstract}

\section{Subject Areas}

Biochemistry, Biotechnology

\section{Keywords}

C. longepaniculatum, Endophytic Fungus, Single Factor, Orthogonal Test

\section{Introduction}

Plant endophytic fungi refers to a type of fungus that grows in the interstitial or 
internal parts of plant tissues during a specific period of life or its life stage, and does not cause significant pathological symptoms in the host plant or does not cause significant damage to the host plant [1]. Studies have found that endophytic fungi can participate in the synthesis and accumulation of plant secondary metabolites, and have similar metabolic pathways to the host, eventually forming the same or similar metabolites [2].

Studies have found that endophytic fungi of $C$. longepaniculatum can promote the synthesis and accumulation of essencial oil [3]; can enhance the activity of protective enzymes in free radical scavenging system [3]; can significantly regulate the genes in the synthesis pathway of monoterpenoids in C. longepaniculatum, so that it is up-regulated [4]; can participate in the signal transduction of plant hormones, and promote the up-regulation of key enzyme gene expression levels in the synthesis of monoterpenoids in C. longepaniculatum [4]; at present, the influence of endophytic fungi on C. longepaniculatum and its mechanism of action are not enough, so it restricts the understanding of endophytic fungi affecting the quality of $C$. longepaniculatum oil. Nowad, many valuable physiologically active substances such as paclitaxel, camptothecin, gibberellin and vincristine have been isolated and identified from the abundant microbial resources of plant endophytic fungi [5]; it is indicated that increasing the yield of active substances in plants can be carried out by searching for effective secondary metabolites from plant endophytic fungal metabolites.

Inducers can be divided into two categories: abiotic inducers and biological inducers. The former refers to physical and chemical stresses such as heavy metal salts, high-concentration salts, antibiotics and ethylene [6]. Studies have found that inducers are substances that alter the strength or pathway of biosynthesis, and the addition of inducers increases the yield of the desired material. Inducers can alter the pathways of secondary metabolite synthesis and the activity of key rate-limiting enzymes in synthetic pathways, allowing metabolism to be synthesized along more efficient pathways [7].

Endophytic bacteria is isolated directly from plants; the content of secondary metabolites is generally low, and industrial batch production is difficult [8] [9], so it is particularly important to improve secondary metabolites in endophytic bacteria in plants. There are many ways to improve secondary metabolites in endophytes in plants, and the use of inducers to affect the accumulation of metabolites is an effective and easy-to-operate method [10].

The endophytic fungi of the $C$. longepaniculatum used in this study have been found to produce substances such as 1,8-eucalyptus [11] [12], but their yield is low and needs to be optimized [13], and with countries People's living standards and economic conditions are rising, and people's demand for natural flavor oil is increasing [14]. The contradiction between supply and demand is prominent. Therefore, this study aims to promote the accumulation of natural products such as 1,8-eucalyptus oil in endophytic fungi of C. longepaniculatum, and to study the effects of different inducers and their combinations on the accumulation of essencial oil in endophytic fungi of $C$. longepaniculatum, based on the previous 
work, single factor and orthogonal experiments were used to optimize the induction conditions of the strains, and the inducers and their combinations which had significant effects on the accumulation of essencial oil in the endophytic fungi of $C$. longepaniculatum were obtained, in order to improve the yield of $C$. longepaniculatum oil, and means to provide a reference basis.

\section{Method and Material}

\subsection{Experimental Materials, Main Drugs and Main Equipment}

\subsubsection{Experimental Materials}

One strain of endophytic fungus (Penicillium commune) was isolated from $C$. longepaniculatum plants. The project team members collected samples with good growth in the preliminary work. After washing, sampling, surface sterilization, plating, and greenhouse culture, the strains were picked out, separated and purified, and then identified by morphology (Specifically, the colony is fluffy as a whole, with a diameter of $1-2 \mathrm{~cm}$, which grows radially to the periphery, the center of the front is green, and the outward gradient is yellowish and white, and the back is milky white [8]), and frozen and preserved by potato dextrose agar medium (PDA).

\subsubsection{Main Drugs and Medium}

Inducers: $\mathrm{CuSO}_{4}, \mathrm{H}_{2} \mathrm{O}_{2}, \mathrm{MnSO}_{4}, \mathrm{FeSO}_{4}, \mathrm{CaSO}_{4}, \mathrm{Li}_{2} \mathrm{SO}_{4}, \mathrm{SA}$ (salicylic acid), Trp (tryptophan), sodium benzoate.

Drugs needed to extract essencial oil: cyclohexane.

Potato dextrose agar medium (PDA): weigh $200 \mathrm{~g}$ of fresh potatoes, weigh 20 $\mathrm{g}$ of glucose, weigh $17-20 \mathrm{~g}$ of agar, and the potatoes are boiled for $30 \mathrm{~min}$, and the filtrate is added to a volume of glucose to $1000 \mathrm{~mL}(17-20 \mathrm{~g})$ of agar was added to the solid medium, and the liquid medium was not added, and the $\mathrm{pH}$ was natural. Streptomycin in an amount of $0.1 \mathrm{~g} / \mathrm{L}$ was added to the medium mainly to inhibit the growth of bacteria.

\subsubsection{Main Instruments}

High-pressure steam sterilization pot (MLS-3780, Japan Matsushita Health Medical Devices Co., Ltd.), high-speed refrigerated centrifuge (Sorvall LYNX6000, Thermos), dual-beam UV-visible spectrophotometer (TU-901, Beijing Pu Analysis General Instrument Co, Ltd.), GC-MS (7890A-5975c, Agilent), constant temperature incubator (LYZ-2102, constant temperature shaker), ultra clean bench (SW-CJ-2FD, Suzhou Purification Equipment Co., Ltd.).

\subsection{Test Design}

The PDB medium with natural $\mathrm{pH}$ was used as the basic medium, and the single factor test of different levels of the same inorganic inducer (Table 1) and the single factor test of different levels of the same organic inducer (Table 2) and Orthogonal test between different inducers (Table 3), the medium was dispensed into a $150 \mathrm{~mL}$ Erlenmeyer flask, and each treatment was repeated for 3 
Table 1. Single factor test of inorganic inducer.

\begin{tabular}{ccccc}
\hline Inorganic inducer & \multicolumn{4}{c}{ different density } \\
\hline $\mathrm{CuSO}_{4}(\mathrm{mmol} / \mathrm{L})$ & 0.01 & 0.02 & 0.03 & 0.04 \\
$\mathrm{FeSO}_{4}(\mathrm{mmol} / \mathrm{L})$ & 0.02 & 0.035 & 0.05 & 0.075 \\
$\mathrm{Li}_{2} \mathrm{SO}_{4}(\mathrm{mg} / \mathrm{l})$ & 0.5 & 1 & 1.5 & 2 \\
$\mathrm{MnSO}_{4}(\mathrm{mmol} / \mathrm{L})$ & 1 & 3 & 5 & 7 \\
$\mathrm{CaSO}_{4}(\mathrm{mg} / \mathrm{l})$ & 0.05 & 0.1 & 0.15 & 0.2 \\
$\mathrm{H}_{2} \mathrm{O}_{2}(\mathrm{mmol} / \mathrm{L})$ & 3 & 6 & 9 & 12 \\
\hline
\end{tabular}

Table 2. Organic inducible single factor test.

\begin{tabular}{ccccc}
\hline Inducer & \multicolumn{5}{c}{ different density } \\
\hline Tryptophan (g/L) & 0.14 & 0.144 & 0.148 & 0.152 \\
SA (mg/l) & 5 & 15 & 25 & 35 \\
Sodium benzoate $(\mathrm{mg} / \mathrm{L})$ & 5 & 10 & 15 & 20 \\
\hline
\end{tabular}

bottles, and sterilized at $115^{\circ} \mathrm{C}$ for $20 \mathrm{~min}$ in an autoclave with an inoculation tool. After cooling, the endophytic fungal strain of the C. longepaniculatum is aseptically operated, and is inserted into the PDB through the inoculation needle in the PDA of the growth, the oil was cultured for $28 \mathrm{~d}$ in $25^{\circ} \mathrm{C}$, and its essencial oil production was measured every $7 \mathrm{~d}$ during its cultivation.

\subsection{Methods}

\subsubsection{Activation of Endophytic Fungal Strains}

The medium was prepared according to the PDA formulation, and the plate, the medium, the inoculation needle, and the like were placed in a sterilizing pot and sterilized at $115^{\circ} \mathrm{C}$ for $20 \mathrm{~min}$. After the sterilization is completed, the ultra-clean workbench is placed, and the plate is inverted; the strain stored in the test tube is inoculated into the medium by the in-situ needle, and then wrapped with plastic wrap, and cultured at $28^{\circ} \mathrm{C}$ for seven $\mathrm{d}$.

\subsubsection{Inducer Single Factor Test}

The natural $\mathrm{pH}$ PDB medium was prepared, and the inorganic inducers were added with equal amounts of inducers after each component, as shown in Table 1, sterilize with an inoculation needle in an autoclave at $115^{\circ} \mathrm{C}$ for $20 \mathrm{~min}$; the organic inducer is sterilized at $115^{\circ} \mathrm{C}$ for $20 \mathrm{~min}$ in a high-pressure steam sterilizer, after cooling, an equal amount of each organic concentration inducer was removed by filtration under a sterile condition using a $0.22 \mu \mathrm{m}$ water filter, as shown in Table 2. The activated endophytic fungal strains were then inoculated into liquid PDA medium, and cultured at $28^{\circ} \mathrm{C}, 120 \mathrm{r} / \mathrm{min}$ for $28 \mathrm{~d}$ in suspension; each concentration was repeated 3 times, and 3 controls were set at the same time.

\subsubsection{Orthogonal Test of Different Inducers}

According to the results of single factor test, after significant test analysis, the 
inducers with significant differences were selected for orthogonal test, the $\mathrm{L}_{16}$ $\left(4^{5}\right)$ orthogonal test (Table 3 ) was carried out with the essencial oil production as an indicator, and each set of experiments was repeated 3 times.

\subsubsection{Extraction and Determination of Essencial Oil from Endophytic Fungi of C. longepaniculatum}

The endophytic fungus of the $C$. longepaniculatum was removed from the culture flask under sterile conditions every $7 \mathrm{~d}$ and dried at $55^{\circ} \mathrm{C}$. Accurately weigh $0.2000-0.6000 \mathrm{~g}$ of endophytic fungus, add 4 times (1:4) of cyclohexane overnight cold soak, then ultrasonic extraction for $30 \mathrm{~min}$, centrifugation at $5000 \mathrm{r} / \mathrm{min}$ at $25^{\circ} \mathrm{C}$ for $4 \mathrm{~min}$, then take the supernatant, the volume was adjusted to $5 \mathrm{~mL}$ with cyclohexane. The liquid was extracted with a syringe, and the filter was filtered into a sample bottle to determine the content of the essencial oil, which was analyzed by GC-MS. Chromatographic conditions: column temperature $60^{\circ} \mathrm{C}$; HP-5MS column, $30 \mathrm{~m} \times 0.250 \mathrm{~mm}$; injection volume $1 \mu \mathrm{L}$; temperature programming: starting from $60^{\circ} \mathrm{C}$, rising to $190^{\circ} \mathrm{C}$ at a heating rate of $10^{\circ} \mathrm{C} / \mathrm{min}$ and maintaining $2 \mathrm{~min}$, then, it is raised to $210^{\circ} \mathrm{C}$ for $2 \mathrm{~min}$ at a heating rate of $5^{\circ} \mathrm{C} / \mathrm{min}$, and then raised to $220^{\circ} \mathrm{C}$ for $8 \mathrm{~min}$ at a heating rate of $10^{\circ} \mathrm{C} / \mathrm{min}$. After injection into GC-MS, the standard curve is obtained, that is, the essencial oil content is obtained. The response value was used to calculate the essencial oil content (1,8-eucalyptol: $\left.Y=73,900 X-299,200, \mathrm{R}^{2}=0.9993\right)$.

\subsubsection{Significance Test of Experimental Data}

The experimental data was input into the DPS and SPSS data processing system tables, and the single factor test statistical analysis was performed in the completely random design of the test statistics tab, and the experimental data was tested for significance; and the experimental result line chart was prepared in an Excel spreadsheet.

\section{Results and Analysis}

\subsection{Effect of Single Factor of Inorganic Inducer on the Yield of Essencial Oil from Endophytic Fungi of C. longepaniculatum}

The natural pH PDB medium was prepared, and the same amount of inorganic inducer was added after the separation, and the activated endophytic strain was inoculated into the liquid PDA medium after sterilization, the essencial oil production was measured on the $7^{\text {th }}, 14^{\text {th }}, 21^{\text {st }}$ and $28^{\text {th }}$ day of $2 \mathrm{~J} 1$ culture, and the effect of single factor of each inorganic inducer on the accumulation of essencial oil in endophytic fungi was studied, the results are shown in Table 3, and the results shown in the table are the average of 3 trials.

Table 3 shows that the endophytic fungi of the $C$. longepaniculatum treated with each inorganic inducer showed an upward trend in the yield of the oil in the range of $21 \mathrm{~d}$, reaching a maximum at $21 \mathrm{~d}$, when the culture time was greater than $21 \mathrm{~d}$, the essencial oil content in endophytic fungi gradually decreases; with the increase of the concentration of inorganic inducer, the yield of 
Table 3. Effects of different inorganic inducer on the accumulation of essential oil of endophytic fungi, 2 J1.

\begin{tabular}{|c|c|c|c|c|}
\hline \multirow{2}{*}{ Time (d) } & \multicolumn{4}{|c|}{ 1,8-eucalyptus (mg/L) } \\
\hline & $7 \mathrm{~d}$ & $14 \mathrm{~d}$ & $21 \mathrm{~d}$ & $28 \mathrm{~d}$ \\
\hline $\mathrm{CuSO}_{4}(0.010 \mathrm{mmol} / \mathrm{L})$ & 0.0373 & 0.0432 & 0.0544 & 0.0437 \\
\hline $\mathrm{CuSO}_{4}(0.020)$ & 0.0395 & 0.0498 & 0.0578 & 0.0452 \\
\hline $\mathrm{CuSO}_{4}(0.030)$ & 0.0417 & 0.0563 & $0.0617^{\star}$ & 0.0585 \\
\hline $\mathrm{CuSO}_{4}(0.040)$ & 0.0389 & 0.0422 & 0.0510 & 0.0449 \\
\hline $\mathrm{FeSO}_{4}(0.020 \mathrm{mmol} / \mathrm{L})$ & 0.0389 & 0.0502 & 0.0651 & 0.0530 \\
\hline $\mathrm{FeSO}_{4}(0.035)$ & 0.0402 & 0.0534 & 0.0673 & 0.0592 \\
\hline $\mathrm{FeSO}_{4}(0.050)$ & 0.0463 & 0.0573 & $0.0691^{*}$ & 0.0619 \\
\hline $\mathrm{FeSO}_{4}(0.075)$ & 0.0404 & 0.0526 & 0.0664 & 0.0541 \\
\hline $\mathrm{Li}_{2} \mathrm{SO}_{4}(0.5 \mathrm{mg} / \mathrm{l})$ & 0.0488 & 0.0519 & 0.0604 & 0.0539 \\
\hline $\mathrm{Li}_{2} \mathrm{SO}_{4}(1.0)$ & 0.0516 & 0.0549 & 0.0662 & 0.0546 \\
\hline $\mathrm{Li}_{2} \mathrm{SO}_{4}(1.5)$ & 0.0556 & 0.0574 & $0.0697^{\star}$ & 0.0569 \\
\hline $\mathrm{Li}_{2} \mathrm{SO}_{4}(2.0)$ & 0.0434 & 0.0559 & 0.0675 & 0.0551 \\
\hline $\mathrm{MnSO}_{4}(1 \mathrm{mmol} / \mathrm{L})$ & 0.0528 & 0.0603 & 0.0735 & 0.0701 \\
\hline $\mathrm{MnSO}_{4}(3)$ & 0.0624 & 0.0693 & $0.0819^{* *}$ & 0.0793 \\
\hline $\mathrm{MnSO}_{4}(5)$ & 0.0563 & 0.0671 & 0.0787 & 0.0721 \\
\hline $\mathrm{MnSO}_{4}(7)$ & 0.0533 & 0.0629 & 0.0742 & 0.0606 \\
\hline $\mathrm{CaSO}_{4}(0.5 \mathrm{mg} / \mathrm{l})$ & 0.0678 & 0.0708 & 0.0775 & 0.0719 \\
\hline $\mathrm{CaSO}_{4}(1.0)$ & 0.0711 & 0.0742 & 0.0808 & 0.0723 \\
\hline $\mathrm{CaSO}_{4}(1.5)$ & 0.0760 & 0.0817 & $0.0934^{\star \star}$ & 0.0814 \\
\hline $\mathrm{CaSO}_{4}(2.0)$ & 0.0707 & 0.0766 & 0.0816 & 0.0714 \\
\hline $\mathrm{H}_{2} \mathrm{O}_{2}(3 \mathrm{mmol} / \mathrm{L})$ & 0.0597 & 0.0634 & 0.0724 & 0.0632 \\
\hline $\mathrm{H}_{2} \mathrm{O}_{2}(6)$ & 0.0612 & 0.0663 & 0.0738 & 0.0693 \\
\hline $\mathrm{H}_{2} \mathrm{O}_{2}(9)$ & 0.0646 & 0.0693 & $0.0783^{\star *}$ & 0.0747 \\
\hline $\mathrm{H}_{2} \mathrm{O}_{2}(12)$ & 0.0572 & 0.0629 & 0.0718 & 0.0615 \\
\hline Control & 0.0368 & 0.0489 & 0.0532 & 0.0421 \\
\hline
\end{tabular}

Note: ${ }^{*}$ There is a significant difference between each column of inorganic inducers $(\mathrm{P}<0.05) ;{ }^{* *} \mathrm{P}<0.01$.

essencial oil increased first and then decreased, and the yield increased compared with the group without added inducer (CK); the effects of essencial oil accumulation on endophytic fungi treated with inorganic inducers were basically consistent with the trend. Among them, on the $21^{\text {st }}$ day, the induced concentrations of $\mathrm{CuSO}_{4}, \mathrm{FeSO}_{4}, \mathrm{Li}_{2} \mathrm{SO}_{4}, \mathrm{MnSO}_{4}, \mathrm{CaSO}_{4}$ and $\mathrm{H}_{2} \mathrm{O}_{2}$ were $0.03 \mathrm{mmol} / \mathrm{L}, 0.05$ $\mathrm{mmol} / \mathrm{L}, 1.5 \mathrm{mg} / \mathrm{L}, 3 \mathrm{mmol} / \mathrm{L}, 1.5 \mathrm{mg} / \mathrm{L}, 9 \mathrm{mmol} / \mathrm{L}$, respectively, the essencial oil production is the largest under the treatment of this inorganic inducer, they were $0.0617 \mathrm{mg} / \mathrm{L}, 0.0691 \mathrm{mg} / \mathrm{L}, 0.0697 \mathrm{mg} / \mathrm{L}, 0.0819 \mathrm{mg} / \mathrm{L}, 0.0934 \mathrm{mg} / \mathrm{L}$, and $0.0783 \mathrm{mmol} / \mathrm{L}$, respectively. The yield increased by $15.98 \%, 29.89 \%, 31.02 \%$, 
and $53.95 \%, 75.56 \%, 47.18 \%$, respectively. According to the significance test, the induced concentrations of $\mathrm{CuSO}_{4}, \mathrm{FeSO}_{4}, \mathrm{Li}_{2} \mathrm{SO}_{4}, \mathrm{MnSO}_{4}, \mathrm{CaSO}_{4}$ and $\mathrm{H}_{2} \mathrm{O}_{2}$ were $0.03 \mathrm{mmol} / \mathrm{L}, 0.05 \mathrm{mmol} / \mathrm{L}, 1.5 \mathrm{mg} / \mathrm{L}, 3 \mathrm{mmol} / \mathrm{L}$ and $1.5 \mathrm{mg} / \mathrm{L}$, respectively. At 9 $\mathrm{mmol} / \mathrm{L}$, there was a significant difference in the yield of 1,8-eucalyptus oil and other concentrations under the inducer at this time $(\mathrm{P}<0.05)$. According to the DPS significance test, the significant difference of $\mathrm{CaSO}_{4}$ was the most significant compared with other inorganic inducers on the $21^{\text {st }}$ day.

\subsection{Effect of Organic Inducer Single Factor on the Yield of Essencial Oil from Endophytic Fungi of $C$. longepaniculatum}

Prepare PDB medium of natural $\mathrm{pH}$, add the same amount of organic inducer after sterilization and cooling, and inoculate the activated endophytic strain into liquid PDA medium, the yield of essencial oil was measured on the $7^{\text {th }}, 14^{\text {th }}, 21^{\text {st }}$ and $28^{\text {th }}$ day of $2 \mathrm{~J} 1$ culture, and the effect of single factor of organic inducer on the yield of essencial oil from endophytic fungus was studied. The results are shown in Table 4; the result is the average of 3 trials.

Table 4 shows that the endophytic fungi of $C$. longepaniculatum treated with organic inducers showed an increase in the yield of essencial oil in the range of $21 \mathrm{~d}$, reaching a maximum at $21 \mathrm{~d}$, when the culture time was greater than $21 \mathrm{~d}$ when the content of essencial oil in endophytic fungi gradually decreases; with the increase of organic inducer concentration, the yield of essencial oil increased first and then decreased, and the yield increased compared with the group without added inducer (CK); the effects of essencial oil accumulation on the endophytic fungi of $C$. longepaniculatum under the treatment of organic inducers

Table 4. Effects of different organic inducer on the accumulation of essencial oil in 2J1.

\begin{tabular}{|c|c|c|c|c|}
\hline \multirow{2}{*}{ Time (d) } & \multicolumn{4}{|c|}{ 1,8-eucalin (mg/L) } \\
\hline & $7 \mathrm{~d}$ & $14 \mathrm{~d}$ & $21 \mathrm{~d}$ & $28 \mathrm{~d}$ \\
\hline Tryptophan $(0.140 \mathrm{~g} / \mathrm{L})$ & 0.0464 & 0.0505 & 0.0578 & 0.0551 \\
\hline Tryptophan (0.144) & 0.0475 & 0.0529 & 0.0596 & 0.0576 \\
\hline Tryptophan (0.148) & 0.0499 & 0.0567 & $0.0627^{\star}$ & 0.0602 \\
\hline Tryptophan (0.152) & 0.0489 & 0.0537 & 0.0607 & 0.0575 \\
\hline $\mathrm{SA}(5 \mathrm{mg} / \mathrm{l})$ & 0.0524 & 0.0616 & 0.0701 & 0.0682 \\
\hline SA (15) & 0.0534 & 0.0674 & $0.0736^{* *}$ & 0.0701 \\
\hline SA (25) & 0.0517 & 0.0623 & 0.0685 & 0.0634 \\
\hline SA (35) & 0.0503 & 0.0607 & 0.0653 & 0.0622 \\
\hline Sodium benzoate $(5 \mathrm{mg} / \mathrm{L})$ & 0.0485 & 0.0572 & 0.0678 & 0.0632 \\
\hline Sodium benzoate (10) & 0.0509 & 0.0604 & $0.0704^{*}$ & 0.0665 \\
\hline Sodium benzoate (15) & 0.0502 & 0.0586 & 0.0659 & 0.0622 \\
\hline Sodium benzoate (20) & 0.0478 & 0.0562 & 0.0632 & 0.0602 \\
\hline Control & 0.0368 & 0.0489 & 0.0532 & 0.0421 \\
\hline
\end{tabular}

Note: ${ }^{\star}$ There is a significant difference in organic inducers $(\mathrm{P}<0.05) ;{ }^{* *} \mathrm{P}<0.01$. 
were basically consistent with the trend. Among them, on the $21^{\text {st }}$ day, when the concentrations of tryptophan, SA and sodium benzoate were $0.148 \mathrm{~g} / \mathrm{L}, 15 \mathrm{mg} / \mathrm{L}$ and $10 \mathrm{mg} / \mathrm{L}$, respectively, the essencial oil yield was the largest under the treatment of organic inducers, the yields were $0.0627 \mathrm{mg} / \mathrm{L}, 0.0736 \mathrm{mmol} / \mathrm{L}$, and $0.0704 \mathrm{mmol} / \mathrm{L}$, respectively, and the yield increased by $17.86 \%, 38.35 \%$, and $32.33 \%$, respectively; after significant test analysis, at $21 \mathrm{~d}$, the tryptophan, $\mathrm{SA}$, and sodium benzoate induced concentrations of $0.148 \mathrm{~g} / \mathrm{L}, 15 \mathrm{mg} / \mathrm{l}, 10 \mathrm{mg} / \mathrm{l}$, 1,8 -eucalyptus oil production and this time there was a significant difference in the treatment of other concentrations under the inducer $(P<0.05)$. The results indicated that there was a positive correlation between the accumulation of essencial oil in endophytic fungi and the concentration of organic inducers.

\subsection{Different Inducer Orthogonal Test}

Orthogonal test selected $\mathrm{CaSO}_{4}, \mathrm{H}_{2} \mathrm{O}_{2}, \mathrm{MnSO}_{4}$, SA, four kinds of substances with significant differences compared with other substances under the single factor of the inducer, and the $\mathrm{L}_{16}\left(4^{5}\right)$ orthogonal test was carried out with the essencial oil yield as the index (Table 5). The results of the variance analysis of the essencial oil production in the inducer induction test are shown in Table 6. The variance analysis of essencial oil yields in different orthogonal experiments showed that the inducer for the significant difference in essencial oil production was $\mathrm{CaSO}_{4}$, and the other three inducers did not reach significant levels for essencial oil production. Through the orthogonal test Table 5, the magnitude of the $\mathrm{R}$ value of the four factors, the impact on the essencial oil production is: $\mathrm{CaSO}_{4}>$ $\mathrm{MnSO}_{4}>\mathrm{H}_{2} \mathrm{O}_{2}>\mathrm{SA}$.

After comparing and comprehensively analyzing the $\mathrm{K}$ value of each factor in the orthogonal test table of different inducers and the comprehensive analysis of the essencial oil production of each group, the optimal combination of 4 groups was selected, that is, the $\mathrm{A}_{4} \mathrm{~B}_{4} \mathrm{C}_{1} \mathrm{D}_{4}, \mathrm{~A}_{4} \mathrm{~B}_{4} \mathrm{C}_{4} \mathrm{D}_{4}, \mathrm{~A}_{4} \mathrm{~B}_{4} \mathrm{C}_{1} \mathrm{D}_{1}, \mathrm{~A}_{4} \mathrm{~B}_{4} \mathrm{C}_{4} \mathrm{D}_{1} 4$ groups were selected for verification test. The results showed that when $\mathrm{CaSO}_{4} 2.0 \mathrm{mg} / \mathrm{L}$, $\mathrm{H}_{2} \mathrm{O}_{2} 12 \mathrm{mmol} / \mathrm{L}$, SA $5 \mathrm{mg} / \mathrm{L}, \mathrm{MnSO}_{4} 7 \mathrm{mmol} / \mathrm{L}$ were added to $\mathrm{PDB}$, the yield was the highest, which was $0.1847 \mathrm{mg} / \mathrm{L}$, which was $247.18 \%$ higher than that without inducer (Table 6).

\section{Conclusions and Discussion}

Studies have found that the addition of inducers can alter the pathway of secondary metabolite synthesis; it can also promote or inhibit the activity of key rate-limiting enzymes in the bio-metabolite synthesis pathway; it also inhibits enzyme activity in unrelated bypass metabolic pathways [7]. Inducers alter the biosynthetic pathway or intensity, allowing the reactants to synthesize as much as possible the desired metabolites and increase their yield [4] [7]. Qi Li [7] found that the addition of prodrugs and elicitors to the fermentation broth of paclitaxel endophytic fungus TMS-26 can effectively increase the yield of paclitaxel; this experiment showed that the effects of different inducers on the yield of 
Table 5. Orthogonal test of different inducers.

\begin{tabular}{|c|c|c|c|c|c|c|}
\hline \multirow{2}{*}{ Test number } & \multicolumn{5}{|c|}{ Factor Factor } & \multirow{2}{*}{$\frac{1,8 \text {-eucalyptus }}{\mathrm{mg} / \mathrm{l}}$} \\
\hline & $\mathrm{A}$ & B & $\mathrm{C}$ & $\mathrm{D}$ & IS & \\
\hline 1 & $1(0.5)$ & $1(3)$ & $1(5)$ & $1(1)$ & & 0.0973 \\
\hline 2 & $2(1)$ & $2(6)$ & 1 & $2(3)$ & & 0.1091 \\
\hline 3 & $3(1.5)$ & $3(9)$ & 1 & $3(5)$ & & 0.1305 \\
\hline 4 & $4(2)$ & $4(12)$ & 1 & $4(7)$ & & 0.1808 \\
\hline 5 & 2 & 4 & $3(25)$ & 1 & & 0.1296 \\
\hline 6 & 4 & 3 & $2(15)$ & 1 & & 0.1669 \\
\hline 7 & 3 & 2 & $4(35)$ & 1 & & 0.1285 \\
\hline 8 & 1 & 4 & 4 & 3 & & 0.1054 \\
\hline 9 & 4 & 1 & 4 & 2 & & 0.1555 \\
\hline 10 & 1 & 3 & 3 & 2 & & 0.0921 \\
\hline 11 & 2 & 3 & 4 & 4 & & 0.1175 \\
\hline 12 & 2 & 1 & 2 & 3 & & 0.0903 \\
\hline 13 & 3 & 1 & 3 & 4 & & 0.1062 \\
\hline 14 & 3 & 4 & 2 & 2 & & 0.1404 \\
\hline 15 & 4 & 2 & 3 & 3 & & 0.1606 \\
\hline 16 & 1 & 2 & 2 & 4 & & 0.0865 \\
\hline $\mathrm{k} 1$ & 0.3804 & 0.4493 & 0.5177 & 0.5223 & & \\
\hline $\mathrm{k} 2$ & 0.4465 & 0.4847 & 0.4841 & 0.4971 & & \\
\hline $\mathrm{k} 3$ & 0.5056 & 0.5070 & 0.4885 & 0.4868 & & \\
\hline $\mathrm{k} 4$ & 0.6638 & 0.5562 & 0.5069 & 0.6638 & & \\
\hline k1 & 0.0951 & 0.1123 & 0.1294 & 0.1306 & & \\
\hline $\mathrm{k} 2$ & 0.1116 & 0.1212 & 0.1210 & 0.1243 & & \\
\hline k3 & 0.1264 & 0.1268 & 0.1221 & 0.1217 & & \\
\hline k4 & 0.1660 & 0.1391 & 0.1267 & 0.1660 & & \\
\hline $\mathrm{R}$ & 0.0709 & 0.0267 & 0.0084 & 0.0443 & & \\
\hline
\end{tabular}

Note: A: $\mathrm{CaSO}_{4}(\mathrm{mg} / \mathrm{L}) ; \mathrm{B}: \mathrm{H}_{2} \mathrm{O}_{2}(\mathrm{mmol} / \mathrm{L}) ; \mathrm{C}: \mathrm{SA}(\mathrm{mg} / \mathrm{l}) ; \mathrm{D}: \mathrm{MnSO}_{4}(\mathrm{mmol} / \mathrm{L})$.

Table 6. Analysis of variance of essencial oil accumulation in orthogonal experiment of different inducers.

\begin{tabular}{|c|c|c|c|c|c|}
\hline Variance source SV & Square sum SS & Degree of freedom df & Mean square MS & $\mathrm{F}$ & $\mathrm{P}$ \\
\hline A & 0.0975 & 3 & 0.0325 & 1.427 & * \\
\hline B & 0.0671 & 3 & 0.0224 & 0.982 & \\
\hline $\mathrm{C}$ & 0.0633 & 3 & 0.0211 & 0.926 & \\
\hline $\mathrm{D}$ & 0.0613 & 3 & 0.0204 & 0.897 & \\
\hline Error & 0.0911 & 4 & 0.0228 & & \\
\hline Total variation & 0.3803 & 16 & & & \\
\hline
\end{tabular}

Note: ${ }^{\star} \mathrm{P}<0.01$. 
essencial oil from endophytic fungi of $C$. longepaniculatum were different, indicating that different inducers could affect the accumulation of essencial oil of endophytic fungi to different extents.

In the single factor experiment, the endophytic fungi were treated with inorganic inducers $\mathrm{CaSO}_{4}, \mathrm{H}_{2} \mathrm{O}_{2}$ and $\mathrm{MnSO}_{4}$, and the essencial oil yield was significantly different from other inducers $(\mathrm{P}<0.05)$, and $\mathrm{CaSO}_{4}$ is more significant than the other two; the yield is larger, reaching $0.0934 \mathrm{mg} / \mathrm{l}$, which is $75.56 \%$ higher than CK; this is related to the fact that calcium ions are activators of certain enzymes, which activate certain secondary metabolic pathways to increase metabolite production, and also have an effect on the permeability of calcium ions to cells and the phosphate content in the medium [15]; $\mathrm{H}_{2} \mathrm{O}_{2}$ acts as a signaling molecule at low doses to regulate gene expression and signaling and thereby regulate secondary metabolic pathways [16]; the yield of essencial oil from $\mathrm{CuSO}_{4}, \mathrm{FeSO}_{4}$ and $\mathrm{Li}_{2} \mathrm{SO}_{4}$ was higher than that of $\mathrm{CK}$, but the difference was not significant, which promoted the accumulation of essencial oil, but it was not significant; the specific reasons need further study. In summary, the promoting effect of inorganic inducers on the accumulation of essencial oil in endophytic fungi of $C$. longepaniculatum is: $\mathrm{CaSO}_{4}>\mathrm{MnSO}_{4}>\mathrm{H}_{2} \mathrm{O}_{2}$.

Treatment of endophytic fungi with organic inducer SA can significantly promote the yield of essencial oil from endophytic fungi of C. longepaniculatum, reaching $0.0736 \mathrm{mmol} / \mathrm{L}$, which is $38.35 \%$ higher than CK. It was found that $\mathrm{SA}$ participates in the signal transduction process as a signal molecule, activates and inhibits the corresponding transcription factors, affects the expression of genes and regulates the synthesis of secondary metabolites [17] [18]. In summary, the organic inducer promoted the accumulation of essencial oil in endophytic fungi of C. longepaniculatum: SA > sodium benzoate > tryptophan. Therefore, based on the difference in the accumulation of essencial oil, the dominant inducer can be found, thereby optimizing the way to induce the accumulation of essencial oil in endophytic fungi.

In the orthogonal experiment, the yield of essencial oil from endophytic fungi was significantly different between $\mathrm{CaSO}_{4}$ and $\mathrm{H}_{2} \mathrm{O}_{2}, \mathrm{MnSO}_{4}$ and SA. The three inducers did not reach a significant level for the production of essencial oil; the effect of promoting the essencial oil production in the orthogonal test was: Ca$\mathrm{SO}_{4}>\mathrm{MnSO}_{4}>\mathrm{H}_{2} \mathrm{O}_{2}>\mathrm{SA}$. The orthogonal test showed that when $\mathrm{CaSO}_{4} 2.0$ $\mathrm{mg} / \mathrm{L}, \mathrm{H}_{2} \mathrm{O}_{2} 12 \mathrm{mmol} / \mathrm{L}, \mathrm{SA} 5 \mathrm{mg} / \mathrm{L}, \mathrm{MnSO}_{4} 7 \mathrm{mmol} / \mathrm{L}$ were added to $\mathrm{PDB}$, the maximum yield of essencial oil was $0.1847 \mathrm{mg} / \mathrm{L}$, which was less than that of $\mathrm{CK}$ without inducer; the output increased by $247.18 \%$; this indicates that the orthogonal combination of different inducers has the best induction effect on the yield of endophytic fungi essencial oil; this suggests that the inducers in several different pathways added simultaneously have synergistic effects [7].

In this experiment, the effects of nine inducers and their partial combinations on the accumulation of essencial oil in endophytic fungi of $C$. longepaniculatum were studied, which promoted the accumulation of essencial oil to a certain ex- 
tent, but it could not be applied to large-scale production. For example, there is no secondary metabolic pathway for the endophytic fungus 2J1 essencial oil. In the future, in the process of strain culture, we can also optimize the culture conditions for its growth stage and metabolite synthesis stage; therefore, it lays a foundation for the artificial regulation and optimization of endophytic fungi and the induction of microbial secondary metabolite accumulation.

\section{Acknowledgements}

The first author acknowledges that this work was supported by Scientific Research Project of Yibin University (Grant No. 2015PY01).

\section{Conflicts of Interest}

The authors declare no conflicts of interest regarding the publication of this paper.

\section{References}

[1] Tan, R. and Zou, W. (2001) Endophytes: A Rich Source of Functional Metabolites. Natural Product Reports, 18, 448-459. https://doi.org/10.1039/b100918o

[2] Hussain, H. and Krohn, K. (2007) Bioactive Chemical Constituents of Two Endophytic Fungi. Biochemical Systematics and Ecology, 35, 898-900. https://doi.org/10.1016/j.bse.2007.04.011

[3] Kuan, Y., Fang, C., Qin, W., et al. (2017) Effects of Endophytic Fungi on the Accumulation and Physiological and Biochemical Characteristics of Essential Oil from $C$. longepaniculatum. Biotechnology Bulletin, 33, 138-143.

[4] Ma, X.W. (2016) Transcriptome Analysis of Stress and Stress of CkNF-YB1 and CkEDS1 in Cynanchum Komarovii.

[5] Liu, J., Ding, G., Fang, L., et al. (2014) Study on Secondary Metabolites of Endophytic Fungus Penicillium polonicum. Chinese Journal of Traditional Chinese Medicine, 39, 3974-3977.

[6] Eilert, U. (1987) Elicitation: Methodology and Aspects of Application. In: Constabel, F. and Vasil, I.K., Eds., Cell Culture and Somatic Cell Genetics of Plants, Vol. 4, Academic Press, New York, 153.

[7] Yan, L., Tang, C. and Yang, S. (2015) Optimization of Paclitaxel Fermentation System for Aspergillus fumigatus TMS-26 by Precursors and Elicitors and Fermentation Conditions. Journal of Fungal Materials, 34, 1165-1175.

[8] Song, Q., Huang, Y., Yang, H., et al. (2012) Optimization of Fermentation Conditions for Antibiotic Production by Actinomycetes YJ1 Strain against Sclerotinia sclerotiorum. Agricultural Sciences, 4, 95.

[9] Ruiz-sanche, Z.J., Flores-Bustamantezr, Dendooven, L., et al. (2010) A Comparative Study of Taxol Production in Liquid and Solid-State Fermentation with Nigrospora sp. a Fungus Isolated from Taxus Globosa. Applied Microbiology, 109, 2144-2150.

[10] Wu, X. (2013) Effects of Seed Extracts of Peach Blossom on Its Endophytic Active Compounds. Biotechnology Bulletin, No. 10, 93-97.

[11] Wang, T., You, L., Huang, N.Y., et al. (2009) Antifungal Activities against Phytopathogens and Diversity of Endophytic Fungi Isolated from C. longepaniculatum. Jiangsu Journal of Agricultural Sciences, 1, 98-101. 
[12] You, L., Wang, T., Li, L., et al. (2009) Analyses on Volatile Organic Compound of 78 Endophytic Fungi Isolated from C. longepaniculatum. Journal of Northwest Agriculture and Forestry University, Natural Science Edition, 37, 193-198.

[13] Tan, Y., Lu, H., Li, Q., et al. (2015) Effects of Camphor Oil on Active Compounds in Endophytic Fungi of C. longepaniculatum. Natural Product Research and Development, 27, 1070-1075.

[14] Wang, T., Wei, S. and Wei, Q. (2007) Diversity of Endophytic Fungi in C. longepaniculatum Leaves. Journal of Yunnan University (Natural Science Edition), 29, 300-302.

[15] Sun, T., Zhao, C. and Jin, F. (2002) Effects of Several Inorganic Ions on Physiological Metabolism of $S$. cerevisiae and Mechanism of Acid Production in Fermentation Process. Journal of Dalian Institute of Light Industry, No. 1, 29-32.

[16] Jeon, B.K., Kwon, K., Kang, J.L., et al. (2015) Csk-Induced Phosphorylation of Src at Tyrosine 530 Is Essential for $\mathrm{H}_{2} \mathrm{O}_{2}$-Mediated Suppression of ERK1/2 in Human Umbilical Vein Endothelial Cells. Scientific Reports, 5, 1-15. https://doi.org/10.1038/srep12725

[17] Cocetta, G., Rossoni, M., Gardana, C., et al. (2015) Methyl Jasmonate Affects Phenolic Metabolism and Gene Expression in Blueberry (Vaccinium corymbosum). Physiologia Plantarum, 153, 269-283. https://doi.org/10.1111/ppl.12243

[18] Cao, H., Nuruzzarnan, M., Xiu, H., et al. (2015) Transcriptome Analysis of Methyl Jasmonate-Elicited Panax Ginseng Adventitious Roots to Discover Putative Ginsenoside Biosynthesis and Transport Genes. International Journal of Molecular Sciences, 16, 3035-3057. 